\title{
Hygrothermal Monitoring of Replacement Infill Panels for Historic Timber- Frame Buildings: Initial Findings
}

\author{
Dr Chris J. Whitman ${ }^{a *}$, Prof Oriel Prizeman ${ }^{\mathrm{a}}$, Prof Pete Walker ${ }^{\mathrm{b}}$, Iain McCaig ${ }^{\mathrm{c}}$, Soki Rhee-Duverne ${ }^{\mathrm{c}}$ \\ a Welsh School of Architecture, Cardiff University, Cardiff, UK \\ $b$ Department of Architecture \& Civil Engineering, University of Bath, Bath, UK \\ c Historic England, UK
}

\begin{abstract}
Energy retrofits aim to improve the thermal performance of buildings' external envelopes. With buildings of traditional construction there exists the risk that these improvements may lead to interstitial condensation and moisture accumulation. For historic timber-framed buildings, this potentially exposes the embedded historic timbers to conditions favouring fungal decay and insect infestation. Hygrothermal digital simulations can assess this risk, however these have limitations, especially regarding the study of historic and traditional materials, due to a lack of accurate data. The research presented in this paper therefore utilizes the monitoring of physical test panels to examine the performance of four replacement infill details. The paper focuses on the design and construction of the test cell and presents initial results from the first year of monitoring. Peer-review under the responsibility of the organizing committee of the ICMB21.
\end{abstract}

Keywords: Interstitial Hygrothermal Behaviour; Moisture Content; Monitoring

\section{Introduction}

In order to meet the decarbonization targets set by the UK Government [1] it is necessary to address the performance of our existing building stock, including those of traditional construction generally built pre-1919. It is however important that improvements to the thermal performance of these buildings' external envelopes do not lead to unintended consequences [2]. To date the majority of research in this field has focused on solid masonry construction [3-4]. However, for historic timber-framed buildings, of which there exist over 68,000 built pre-1850 [5], changes to the hygrothermal performance of their exposed timberframed walls could increase the risk of fungal decay and insect attack. This paper presents research, funded by Historic England that aims to address this previously under researched area.

\subsection{Aims and Objectives}

The research aims to establish the risk of interstitial condensation and moisture accumulation within four potential replacement infill panels for timber-framed buildings, traditional wattle-and-daub, a composite of wood fibre and wood wool boards, expanded cork board, and hempcrete. Thermal performance and moisture content will be monitored over a minimum of two years, with hygrothermal conditions compared to those favourable for fungi and insects known to endanger hardwood frames. In the future, measured results will also be compared to those arising from digital hygrothermal simulation using WUFI ${ }^{\circledR}$ Pro. The results will be used to corroborate previous research by the authors using in situ monitoring [6] and laboratory testing [7].

\section{Methodology}

A test cell has been constructed at Cardiff University to create a controlled internal environment, of which the test panels form the external envelope of the northern façade, their outer face exposed to the Cardiff climate. The dimensions of the test panels were determined following a study of a representative sample of 100 historic timber-framed buildings with exposed timber frames. An array of eight of these panels, constructed using reclaimed oak, allows for the monitoring of pairs of panels of each of the aforementioned infill materials (fig. $1 \mathrm{a} \& \mathrm{~b}$ ). One of each pair is finished internally and externally with a natural hydraulic lime plaster NHL 3.5 (Secil ${ }^{\mathrm{TM}}$ ), whilst the other is finished in a non-hydraulic lime hemp plaster (Ty Mawr Lime Ltd.). Temperature $\left({ }^{\circ} \mathrm{C}\right)$ and moisture content $(\%)$ are monitored using Type $\mathrm{T}$ thermocouples (temperature) and electrical resistance (moisture content) at a total of 60 positions. These being, at three depths (interface of internal plaster and insulation, mid-depth, and interface of external plaster and insulation) at the centre of each panel, in the horizontal wall plate at the base of each panel, and halfway up the vertical stud at the junction with the panels finished in NHL3.5. The sensors are wired back to a Campbell Scientific CR1000 data logger via AM25T multiplexers for the thermocouples and AM16/32 multiplexers for the moisture measurements,

\footnotetext{
* Corresponding author. +44 (0) 292087 5893, WhitmanCJ@Cardiff.ac.uk
} 
with measurements at 30 minute intervals. The internal temperature $\left({ }^{\circ} \mathrm{C}\right)$ and relative humidity $(\mathrm{RH})(\%)$ of the test cell are measured using a Campbell CS215. External temperature $\left({ }^{\circ} \mathrm{C}\right), \mathrm{RH}(\%)$, precipitation $(\mathrm{mm})$, air pressure (mbar), wind speed $(\mathrm{m} / \mathrm{s})$ and wind direction are measured using a Vaisala Weather Transmitter WXT520 Series mounted on the roof of the test cell. Direct solar radiation $\left(\mathrm{W} / \mathrm{m}^{2}\right)$ incident on the test panels is measured using a Kipp and Zohnen CM5 pyrometer.

(a)

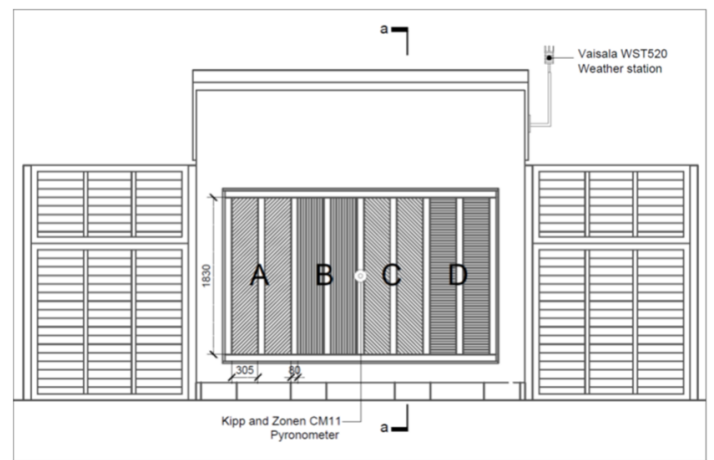

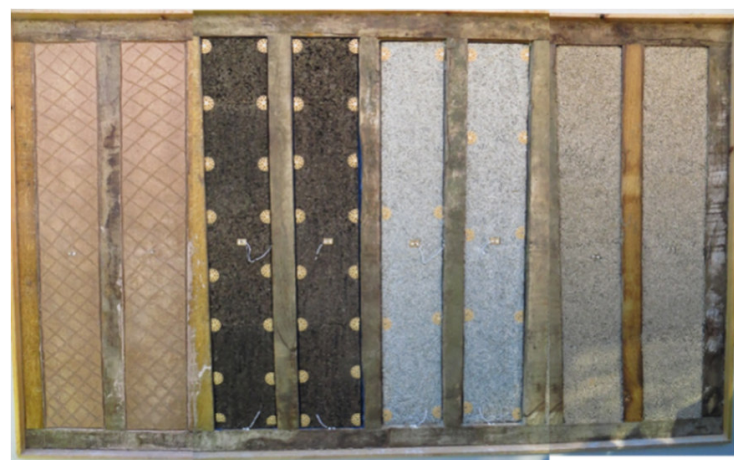

(b)

Figure 1. (a) North elevation of test cell showing pairs of panels, (b) Photograph of panels prior to rendering (Whitman, 2019)

\section{Initial Results and discussion}
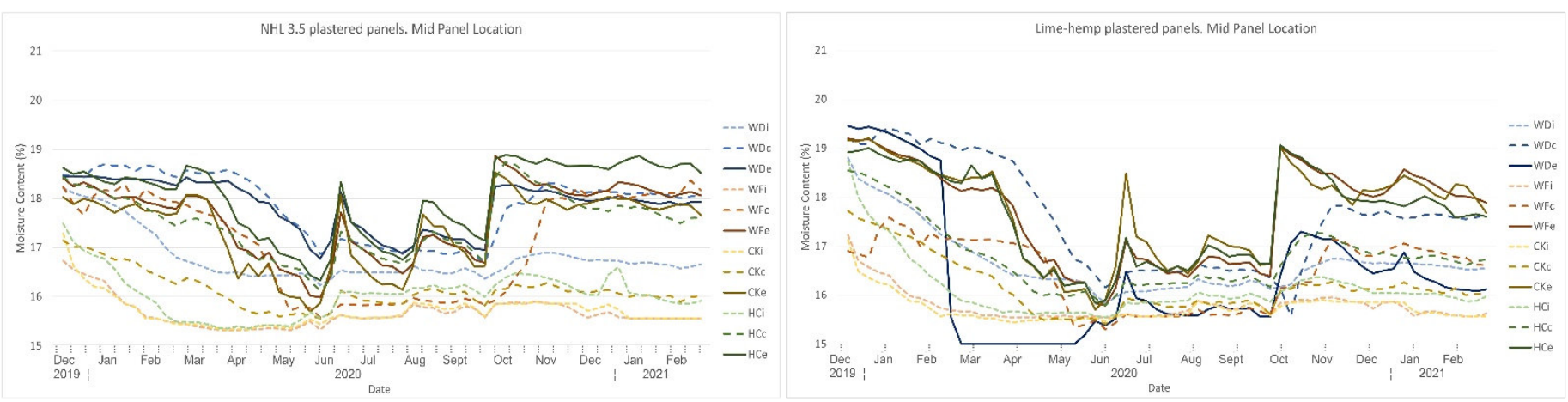

Figure 2. Initial results for monitoring period 12/12/2019-05/02/2021 (a) Panels finished with NHL 3.5, (b) Panels finished with Lime Hemp plaster. (WD-Wattle \& Daub, WF-Wood Fibre, CK-Cork, HL-Hemp-lime. i-internal, c-centre, e-external.)

The initial results (fig 2) show an initial drying period followed by a series of wetting and drying cycles. As yet no evidence of interstitial condensation has been found, with these wetting cycles correlating with climatic measurements of wind-driven rain. Differences can however be observed between the moisture behaviour of different panel infill materials, different finishing plasters and monitoring positions. Infill materials with low moisture permeability are seen to produce higher moisture contents at the interface with the external render due to the concentration of moisture at this point. Those panels finished in the more moisture permeable lime hemp plaster, overall present lower moisture contents, with reduced drying times.

\section{Conclusion}

The initial results indicate the relative impact of the moisture permeability of both infill materials and finishing plasters. The measurements are ongoing and will continue for at least another year. It is hoped that the outcome of this research will assist in the formulation of best practice guidance for the retrofit of historic timber-framed buildings in the UK.

\section{References}

[1] BEIS. UK becomes first major economy to pass net zero emissions law. 2019 29/10/20]; Available from: https://www.gov.uk/government/news/uk-becomesfirst-major-economy-to-pass-net-zero-emissions-law.

[2] Historic England, Energy Efficiency and Historic Buildings: Application of Part L of the Building Regulations to historic and traditionally constructed buildings (Revised 2012), in Online, English Heritage., Editor. 2012, English Heritage: UK. p. 1-63.

[3] D'Ayala, D. and Y.D. Aktas, Moisture dynamics in the masonry fabric of historic buildings subjected to wind-driven rain and flooding. Building and Environment, 2016. 104: p. 208-220.

[4] Baker, P. and S. Rhee-Duverne, A Retrofit of a Victorian Terrace House in New Bolsover a Whole House Thermal Performance Assessment. 2015, Historic England.

[5] Whitman, C.J., The distribution of historic timber-framed buildings in the UK and the impacts of their low energy retrofit. 2017, Cardiff University.

[6] Whitman, C., et al. The impact of modernization of a 16th century timber-framed farmhouse, Suffolk, UK. in The 3rd International Conference on Energy Efficiency in Historic Buildings (EEHB2018), Visby, Sweden, September 26th to 27th, 2018. 2018. Uppsala University.

[7] Whitman, C.J., et al., Energy retrofit infill panels for historic timber-framed buildings in the UK: physical test panel monitoring versus hygrothermal simulation. Architectural Science Review, 2020: p. 1-12. 